\title{
The Ten Crafts: Design and Integration for Developing Creative Economic Products
}

\author{
Phuthipanithid Khongphokhanun ${ }^{1}$, Marisa Koseyayothin ${ }^{2} \&$ Kla Somtrakool ${ }^{1}$ \\ ${ }^{1}$ The Faculty of Cultural Science, Mahasarakham University, Khamriang Sub-District, Kantarawichai District, \\ Maha Sarakham, Thailand \\ ${ }^{2}$ Kanchanapisek Non-Formal Education Centre (Royal Academy), Salaya Sub-District, Bhuttamonthon District, \\ Nakhon Pathom, Thailand \\ Correspondence: Nuengruethai Coulson, 391/12 Moo 5, Nongchang Sub-District, Nongchang District, Uthai \\ Thani, Thailand. E-mail: david.coulson.6@gmail.com
}

Received: December 25, 2012 Accepted: February 9, 2013 Online Published: March 28, 2013

doi:10.5539/ass.v9n4p27 URL: http://dx.doi.org/10.5539/ass.v9n4p27

\begin{abstract}
There are ten important branches of Thai art conserved under royal patronage to protect the artistic heritage of Thailand. The skilled craftsmen and women of the Department of the Ten Crafts are the front line in the defense of national artistic identity and create products that represent Thai culture, society and traditions. This research aims to study wisdom surrounding product creation using the ten crafts, analyze problems in the production process and offer a design and integration method for developing creative economic products. The paper covers three provinces in Central Thailand and discusses factors of local raw materials, invention, creation of art and cultural representation corresponding to the lifestyle of each locality. Current social lifestyle and existence have been urbanized and Thai art and culture is being diluted by the influence of western social culture. This study and design method takes old product models as capital for design development and uses them to develop handiwork originality while retaining identity for cultural transmission. Development must continue to integrate the ten crafts to create suitable and attractive new product models.
\end{abstract}

Keywords: ten crafts, design, integration, product development, creative economy

\section{Introduction}

Art and culture show the progress of a nation. The basis of culture is inherited from many generations and combined with contemporary mental progress to show strength and unity in the maintenance of national identity. Thai society, in both the past and present, has produced consumer goods that are material representations of the country and its artists. Not only do the craftsmen provide a service to the community, but they also enjoy a privileged and unique position in the cultural vanguard, maintaining the heritage of the nation. This unique role was recognized and the artists were officially taken under royal patronage during the Ayutthaya Period of Thai history. A new institution was formed and named Krom Chang Sip Mu, or The Department of the Ten Crafts (Phayakaranon, 1997, p. 36).

There are ten divisions within The Department, important branches considered worthy of conservation and inheritance: a) drawing; b) sculpting; c) carving; d) engraving; e) moulding; f) turning; g) modeling; h) lacquering; i) metal beating; and j) plastering. These are important fine-arts and the artisans must display exceptional craftsmanship, ability and skill in creating magnificent works of art for royal commission. The ten crafts were called 'royal crafts' due to their link to the Thai royal family, noblemen and government officers. Originally, skillful Thai craftsmen were commissioned according to their knowledge and ability. If their work met the expected standards, the artists would be supported with a military pension and earn a new rank, such as Chao Phraya, Phra, Luang, Khun or Muean (Leesuwan, 1979, p. 68). In extreme circumstances, their social status may be upgraded from that of peasant to government officer or nobleman. Since the inauguration of this royally-driven initiative, culture, tradition and religion have been protected and restored, with many craftsmen receiving continuous royal support (Lekagul, 1976, p. 13). Furthermore, the Department of the Ten Crafts has become the leading artistic institution in the country and continues to create artwork for the royal family (Phayakaranon, 1997, p. 83). 
The craftsmen are important social role-models of creation, custom and tradition. The works of ten-craft artisans reflect philosophy, customs, beliefs and traditions. Basic principles can be identified in the artistic interpretation of the models, which frequently depict images of humanity, animals, leaves, flowers, mountains, water surfaces, palaces and houses. These features are created from principles and beliefs that have been regulated and reformed from their original, natural form. These sources of natural inspiration cause the creations to appear either naturally realistic or wonderfully idealistic, depending upon the purpose of the commission.

The present state of art and culture in Thailand is different from its form in the past, especially concerning the work of the ten crafts. Current products have been developed to reach the general market and be affordable by all. These products are important in protecting cultural heritage in the face of modernized society and governmental development of national economy. There has been a forced reaction to social urbanization and it is now possible to differentiate between a set of ancient crafts and a set of present crafts. New products have been developed in the mould of the ancient artifacts but with extra emphasis on beauty and real benefit, satisfying consumer needs and responding to customer demand, both domestically and internationally.

Product design work comes from individual Thai wisdom. If the product is a Thai conception, produced by Thai people, using Thai materials then it will add cultural value to the economy. Rather than merely reflecting the individual inspiration of the artist, product design work showcases the cultural value of the nation. Additionally, the products are not only precious to the consumer but also to the pride, security and protection of Thai cultural values. Complete product design must integrate knowledge of the ten crafts, science of art, science of marketing, science of sales promotion and science of civility. These products are truly priceless, as many goods in society influence lifestyle. Although their monetary worth is negligible, they instill sentiments of value and pride in the consumer. Nevertheless, current product design does not fully convey nor accurately reflect ethnic identity but considers circulation and marketing as the primary objectives. This outlook limits the cultural impact of manufacture. The artistic community must realize that the quality of these products are worthy of promotion and marketing. With this acknowledgement and individual recognition of the importance of their creations, they will give economic value to the overall image of art in Thailand. It is for this reason that the researchers conducted research into the design and integration of the ten crafts for developing economic products.

\section{Research Aims}

This research had three main objectives: a) to study wisdom in product creation using the ten crafts; b) to study the problems with product creation using the ten crafts; c) to offer a design and integration method for developing creative economic products.

\section{Research Methodology}

This research used a cultural qualitative method. A purposive sampling technique was used to generate a total of sixty randomized samples, including fifteen key informants, twenty casual informants and twenty-five general informants. The samples included people living in three provinces of central Thailand, Bangkok, Nonthaburi and Phetchaburi. Data was collected by field notation, structured and non-structured interview, participant and non-participant observation, focus group discussion and workshop. In addition, data reliability and validation tests were performed using a triangulation method. This research is a descriptive analysis and presentation.

\section{Results}

\subsection{Wisdom in Product Creation Using the Ten Crafts}

The base of wisdom for product creation using all ten crafts differs in each province. The main reasons for this are differences in surroundings, basic education, society, native habitat, local raw materials, career context and social conditions within the community. These differences cause variations in the production method. The overall image about wisdom in product creation from ten crafts can be classified into six categories: product type, craft aim, tools, raw materials, procedure and marketing. This study analyzed seven different types of product.

\subsubsection{Grass Relics}

The wisdom for this type of product is obtained through study at the institute of art at Rajamangala Institute of Technology. Pho Chang Campus is the base for sculptor design work. The art is then influenced by the wisdom of the ten crafts during the production process at Phra Kiao foundry. This process includes design adornment and modeling work with Buddha image sculpting, including techniques of beeswax casting.

\subsubsection{Wall Clocks with Pearl Design}

The wisdom for creation of clocks with pearl adornments comes from family inheritance. The chief pearl craftsman in Samut Sakhon Province has been a pearl craftsman and teacher for twenty years. 


\subsubsection{Coconut Shell Products}

Wisdom of the ten crafts related to coconut shell products is studied independently from examples of models and paintings in books. Ideal creations use undesirable coconut shells to make lamp models by integrating knowledge of perforating, carpentry and jewel production.

\subsubsection{Koh Kred Kiln Products}

Ten craft wisdom was transmitted to modern Ban Koh Kred from generation to generation in the family system. Kiln products are part of the heritage and culture of Koh Kred people and use the science of sculptors, modelers and carvers.

\subsubsection{Elephant Wood Carving Products}

The wisdom of the ten crafts is obtained by training of Khon mask craftsman's science at Bang Sai Royal Folk Arts and Crafts Centre, Ayutthaya Province. The wisdom includes modeling, carving, painting, wood-turning and sculpting.

\subsubsection{Enamel Products}

Metal beating wisdom comes from Mother Boonmee Chanurairat, a crafter of nielloware and enamel from Nakhon Si Thammarat Province.

\subsubsection{Palm Wood Turning Products}

Knowledge has been transferred from Father Hun and Mother Anong Onying for the last fifteen years, including knowledge of carpentry and turning using materials from the local area.

\subsection{Problems with Product Creation Using Wisdom of the Ten Crafts}

There are provincial similarities and differences in the product creation problems when using wisdom of the ten crafts in Bangkok, Nonthaburi and Phetchburi. At present, lifestyle and society have been urbanized and Thai art and culture are not popular with the new generations. Modern youth are influenced by western culture in the media. Material society and technology are rapidly destroying the connection with conserved Thai art and culture. The expansion of cities has seen suburbs replace raw material sources. It is also difficult to find successors to the crafts because the new generation is not educated in the real art and culture of the nation, leaving only relatives of current craftsmen to take up the mantle. Some products have a high domestic and international demand but the craftsmen are unable to meet production requirements. Wall clocks with pearl design, grass relics and coconut shell products are sold at various provincial events and OTOP fairs, including those at the IMPACT Arena in Muang Thong Thani, Bangkok. The people who earn a living from ten craft product creation use their own ability, own products, own sales technique and own design. These problems can be solved by developing a specialist position to give guidance about creative model specifications. This would strengthen products from various branches of the ten crafts to add beauty to and increase the value of Thai art.

\subsection{Design Method and Integration for Developing Creative Economic Products}

The method created during this research is intended to modernize old products by developing their design and originality, while still protecting their identity for cultural transmission. Development must continue to integrate work of the ten crafts and support integrated design in accordance with the important processes for that type of craft. The new product models must be suitable for the requirements of the market and consumers, emphasizing integration of ten craft wisdom in order to expand the economic value of the product. In order to achieve these aims, present society must continue to develop old products, using basic knowledge of the ten crafts to increase beauty, elegance and intricacy. Each branch must have a suitable creative development model, including tools, craft processes and technology appropriate to the growth of society. Outdated craft work production should be decreased and discontinued. With these steps in place, high quality products will be created, increasing the value and price of Thai art without hiding its local identity.

\section{Discussion}

A keystone of product creation under the ten crafts, wisdom is part of the cultural heritage of Thai people. Thai wisdom is found in different forms in every province and the local communities are responsible for succession and conservation. From research conducted in Bangkok, Nonthaburi and Phetchaburi it was found that inherited wisdom came from different sources. Wisdom in Bangkok was transferred by craftsmen, Nonthaburi people learned their wisdom from ancient Mon culture and Phetchaburi people inherited their knowledge from the wisdom of craftsman in the Ayutthaya capital, as discussed in the work of Kanit Lekagul (1976, p. 129). Craftsmen who produce substantial quantities of artwork believe in important men or women within their skill 
group. It is the role of these skilled gurus to create custom forms and standards for each kind of craft. They are then able to identify a set of ideals to promote craft succession in society.

In the creation process of craft items, each branch of the ten crafts will have a representative craftsman to have input into the final product. This ensures that Thai art fulfils its potential and becomes distinguished. This action clearly corresponds to the Structural Functionalism Theory, which states that society is a composition of various sub-systems with specific skills and multiple functions. These sub-systems, so the theory states, then cooperate as part of a larger system. The knowledge base of the ten crafts is visible in material art that Thai craftsmen produce. Evident amongst the beauty and elegance are characteristics of Thai art, culture, traditions and customs. This idea was proposed and applied to Thailand in the work of Songkoon Chantachon (2006, p. 14). In summary, the knowledge base of all ten crafts appears in the manufactured products thanks to the handiwork of skilled craftsmen accepted by society to lead the cultural defense against homogeneity and maintain and inherit the art and cultural heritage of Thailand.

Problems with product creation that appeared in all three provinces and seven products studied were the lack of skilled craftsman, educational institutions, knowledge, understanding and integration. As one craftsman cannot complete a product, entrepreneurs must employ additional craftsmen. This causes high investment costs and also makes it very difficult to find enough skilled technicians in the same area. Local raw materials also cause a problem because there are institutions that enjoy a monopoly on the products. These groups will use the best selection of materials from the area and sell imported raw materials from other provinces, such as palm wood, inflating production costs. The final and, perhaps, greatest problem is with technology. Tools are outdated and are not appropriate, given the social conditions demanding technological growth in production. This causes inconvenience to craftsman and makes their work slower. By modernizing technology, the standard of products can be improved.

The method of design and integration for developing creative economic products will increase originality and levels of beauty. These will in turn raise the value of Thai crafts. So, product manufacturers should develop a creative economy, with high importance placed upon the sourcing of local raw materials. This is crucially important and related to every step in the production process, from design to development to sale. Better organized raw material operations will help to modernize old products and increase future circulation. This model thus states the importance of community self-sufficiency in terms of raw materials.

The factor that increases the levels of beauty is the development of patterns from old to new, according to Suddan Wisuttilak (2000, p. 171-175). Modern product creation is achieved by using external influences from other communities and integrating them with the original patterns. This developmental design applies knowledge inherited from ancestors to modern art in order to generate income with community culture as the base and show the main identity of the community, as suggested by Theerapong Wasantadirok (2003, p. 88-94).

Technology is the factor that fully integrates the products, so technology is important for the standardization of product quality and expense (Locher, 2006, p. 150). Entrepreneurs must integrate product development and its effect on marketing and distribution. The marketing is a particularly important key for the success of the product and must meet the requirements of the target market (Kotler 1996, p. 11). Design and integration for development of creative economic products can propel society to the next level.

\section{References}

Alhemoud, A. M. (2003). A tourism marketing plan for Kuwait and other GCC countries. PhD Thesis. The University of Kuwait: S. N.

Aman. (2005). Community Based Tourism in Doi Inthanon National Park: Case Study of Ban Mae Klang. PhD Thesis. The University of Chiang Mai: S. N.

Brown, D. H. (1980). Principle of Language Learning and Teaching. New Jersey: Prentice Hall.

Bruner, P. J. (1986). Economic Nationalism in the Third World. Colorado: Westview Press.

Chantachon, S. (2006). Transmission of folk wisdom to descendents regarding land, water and forest resources. Mahasarakham University: Research Institute of Northeastern Art and Culture.

Cheesmen, P. (1973). Lao Textiles Ancient Symbol-Range Planning. Michigan: The Landis Press.

Choi, S. H., \& Cheung, H. H. (2007) Multi-material virtual prototyping for product development and biomedical engineering. Computers in Industry, 58(5), 438-452. http://dx.doi.org/10.1016/j.compind.2006.09.002

Farmelo, M. (1995). A Classroom on the Mall: Indigenous Women and the Culture of Development. Grassroots Development, 19(1), 35-38. 
Fennell, D. (1999). Ecotourism: An introduction. London: Routledge.

Gee, C. Y., Choy, D. J. L., \& Makens, J. C. (1984). The Travel Industry. Connecticut: The A VI Publish Company Inc.

Jaiherm, A. (2003). Thai Culture and Thai Valuable Identity. Cultural Current, 4(5), 11-14.

Joseph, C. E. (1994, October). Some Factors Influencing Problem Solving Activities: Perceptions of Product Development and Marketing Manager. Dissertation Abstracts International, 55(4), 925-A.

Kotler et al. (1996). Marketing Management. Singapore: Prentice-Hall.

Kotler, P. (1980). Marketing Essentials. New Jersey: Prentice-Hall.

Kotler, P. (1988). Marketing Management. New Jersey: Prentice-Hall.

Krider, J. F. (1994). Heating and Cooling of Buildings: design for efficiency. New York: McGraw-Hill.

Leesuwan, W. (1979). Five Minutes with Thai Artists. Bangkok: Panya Printing.

Lekagul, K. (1976). 'No Artisans, No Art', Anusorn A.S.T. Bangkok: S. N.

Locher, I. R. (2006). Technologies for Systems on Textile Integration. PhD Thesis. Eidgennoessische Technische Hochschule Zuerich (Swizerland): S. N.

Ono, T. (1978). Pagan Mural Painting of the Buddhist Temples in Burma. Japan: Kodonsha.

Phayakaranon, J. (1977). Ten Craft Designers in the Ratworawikan Royal Temple. Bangkok: Tammasart University Press.

Sansombat, Y. (1997). Way of Development to Increase Cultural Village Potential for Tourism Bangkok. Research Report: S. L.:S. N.

Sato, J. (2006). Toward a New Generation of Resource Professionals. Proceedings of a Regional Seminar on Natural Resources and Environment in the Greater Mekong Sub-region, Chiang Rai: S. N.

Schein, E. H. (1985). Organization Culture and Leadership. San Francisco: Jossey Bass

Seibert, S. E. (1994). Social Interaction, Cross-Functional Integration and Project Performance in the New Product Development Process. Dissertation Abstracts International, 55(5), 1320-A.

Veramu, J. (1996, July). Sustainable Development through Community Education in the South Pacific. Community Education International, 6-9.

Wasantadirok, T. (2003). Development model for the silk market and silk production, Buriram Province, Thailand. Buriram: Buriram Rajhabat University.

Williams, R. L. (1994). Essentials of Total Quality Management. New York: Amercom.

Wisuttilak, S. (2000). Changes to Local Cloth Products, Ban Had Seeyow, Sri Satchanarai District, Sukhothai Province, Thailand. Bangkok: Tammasart University Press.

Wongpanich, W. (1996). Tourism Geography. Bangkok: Tammasart University. 